\title{
GAMBARAN BUDAYA KESELAMATAN PASIEN DALAM PELAYANAN KESEHATAN DI RUMAH SAKIT
}

\author{
Elisa Claudia Simanjuntak / 181101114 \\ elclaudia02@gmail.com
}

\begin{abstract}
ABSTRAK
Latar Belakang : Angkainsiden keselamatan pasien di rumah sakit lebih tinggi dibandingkan dengan industri lain. Oleh karena itu, perlu adanya langkah membangun budaya keselamatan pasien.

Tujuan : Tujuan penulisan kajian ini adalah untuk mengetahui gambaran budaya keselamatan pasien di rumah sakit.

Metode : Metode yang digunakan dalam kajian ini adalah literature review, yaitu dengan cara menganalisis, mengeksplorasi serta mengkaji bebas jurnal dan buku teks yang membahas tentang budaya keselamatan pasien di rumah sakit.

Hasil : Budaya keselamatan pertama kali harus dibangun oleh tenaga kesehatan. Budaya keselamatan di rumah sakit dilakukan untuk memberikan rasa aman kepada pasien serta mengurangi angka insiden keselamatan pasien.

Pembahasan : Untuk menjalankan atau meningkatkan keselamatan pasien, perlu ada budaya yang dibangun terlebih dahulu. Budaya keselamatan pasien di rumah sakit, pertama kali harus dilakukan oleh tenaga kesehatan.

Kata Kunci : Budaya Keselamatan Pasien, Pelayanan Kesehatan, Rumah Sakit.
\end{abstract}




\section{Latar Belakang}

Keselamatan pasien telah menjadi isu global bagi rumah sakit. Hal ini karena angka insiden keselamatan pasien masih tinggi. Menurut National Safety Council (Kepmenkes RI, 2007) menyebutkan bahwa terjadinya kecelakaan di rumah sakit $41 \%$ lebih besar dari pekerja di industri lain.

Budaya keselamatan pasien merupakan langkah awal untuk membangun keselamatan pasien. Budaya keselamatan pasien perlu diterapkan, dengan melihat masih tingginya angka insiden keselamatan pasien di rumah sakit. Budaya keselamatan harus diterapkan pertama kali oleh tenaga kesehatan di rumah sakit. Apabila budaya keselamatn pasien berjalan baik, angka insiden keselamatan pasien dapat berkurang. Inti dari budaya keselamatan pasien adalah kepedulian tenaga kesehatan mengenai pentingnya keselamatan pasien.

\section{Tujuan}

Untuk mengetahui gambaran budaya keselamatan pasien di rumah sakit.

\section{Metode}

Metode yang digunakan dalam kajian ini adalah literature review, yaitu dengan cara menganalisis, mengeksplorasi serta mengkaji bebas jurnal dan buku teks yang membahas tentang budaya keselamatan pasien di rumah sakit. Referensi berupa jurnal dan buku teks yang digunakan adalah sebanyak 14. Jurnal yang digunakan sebagai referensi dalam tulisan ini diterbitkan dalam kurun waktu 10 tahun terakhir.

\section{Hasil}

Budaya keselamatan pertama kali harus dibangun oleh tenaga kesehatan. Budaya keselamatan di rumah sakit dilakukan untuk memberikan rasa aman kepada pasien serta mengurangi angka insiden keselamatan pasien.

\section{Pembahasan}

Keselamatan pasien adalah suatu sistem di dalam rumah sakit yang dilakukan untuk memberikan rasa aman kepada pasien selama mendapatkan pengobatan. Untuk menjalankan atau meningkatkan keselamatan pasien, perlu ada budaya yang dibangun terlebih dahulu. Budaya keselamatan pasien di rumah sakit, pertama kali harus 
dilakukan oleh tenaga kesehatan. Tenaga kesehatan adalah orang-orang yang bertanggung jawab terhadap keselamatan pasien.

Budaya keselamatan pasien yang ada dirumah sakit memiliki hubungan langsung terhadap pelaksanaan pelayanan yang bertujuan untuk menjamin keselamatan pasien. Kemudian budaya keselamatan pasien itu sendiri juga dipengaruhi olek kepemimpinan transformasional dalam organisasi tersebut

$$
\text { Berbagai hasil studi }
$$

merekomendasikan untuk memperbaiki upaya keselamatan pasien dengan memperhatikan isu-isu budaya keselamatan pasien dilangkah awal. Survei untuk mengukur budaya keselamatan di rumah sakit kemudian berkembang dan digunakan secara rutin serta berperan dalam memprediksi perhatian RS terhadap keselamatan pasien.

\section{Penutup}

Keselamatan pasien adalah kebutuhan pasien akan rasa aman. Hal ini menjadi tanggung jawab tenaga kesehatan selama pasien di rawat di rumah sakit. Untuk dapat memberikan pelayanan yang baik khususnya bagi keselamatan pasien, tenaga kesehatan harus membangun budaya keselamatan pasien. Budaya keselamatan pasien merupakan langkah awal tercapainya keselamatan pasien di rumah sakit.

\section{Referensi}

Anggraeni, D. dkk. (2016). Pengaruh Budaya Keselamatan Pasien Terhadap Sikap Melaporkan Insiden Pada Perawat di Instalasi Rawat Inap Rumah Sakit Tk. II dr. Soepraoen. Jurnal Aplikasi Manajemen. 14(2): 309-321.

Astini, A. F. (2016). Gambaran Budaya Keselamatan Pasien di RS Stela Maris Makassar. Prosiding Seminar Nasional Penelitian dan PKM Kesehatan. 2(1): 152-163.

Bawelle, S.C. (2013). Hubungan Pengetahuan dan Sikap Perawat dengan Pelaksanaan Keselamatan Pasien (Patient Safety) di Ruang Rawat Inap RSUD Liun Kendage Tahune. eJournal Keperawatan. 1(1):1-7.

Elfrida, S. (2011). Budaya Patient Safety dan Karakteristik KesalahanPelayanan: Implikasi Kebijakan di Salah Satu Rumah Sakit di 
Kota Jambi. Jurnal Kesehatan Masyarakat Nasional. 6(2): 67-76.

Fitriana, Y. \& Pratiwi, K. (2018). Pelaksanaan Patient Safety di Rumah Sakit Umum Daerah dan Rumah Sakit Umum Swasta Bantul Berdasarkan Ketentuan Undang-Undang Nomor 44 Tahun 2009 Tentang Rumah Sakit. Jurnal Kebidanan. 7(1):28-39.

Harus, B. D. \& Sutriningsih, A. (2015). Pengetahuan Perawat Tentang Keselamatan Pasien dengan Pelaksanaan Prosedur Keselamatan Pasien Rumah Sakit (KPRS) di Rumah Sakit Panti Waluya Sawahan Malang. Jurnal CARE. 3(1): 25-32.

Iriviranty, A. (2015). Analisis Budaya Organisasi dan Budaya Keselamatan Pasien Sebagai Langkah Pengembangan Keselamatan Pasien di RSIA Budi Kemuliaan Tahun 2014. Jurnal Administrasi Rumah Sakit. 1(3): 196-206.

Najihah. (2018). Budaya Keselamatan Pasien dan Insiden Keselamatan Pasien di Rumah Sakit : Literature Review. Journal Of Islamic Nursing. 3(1): 1-8.
Pujilestari, A. dkk. (2014). Budaya Keselamatan Pasien di Intalasi Rawat Inap RSUP DR. Wahidin Sudirohusodo Kota Makassar. Jurnal MKMI. 57-64.

Simamora, R. H. (2019). Buku Ajar Pelaksanaan Identifikasi Pasien. UWAIS:Inspirasi Indonesia.

Simamora, R. H. (2019). Documentation of patient Identification into the Electronic System to improve the quality of nursing services. Internasional Journal of Scientific \& Technology Reasearch.

Simamora, R. H. (2019). The influence Of Training Handover based SBAR Communication for improving patients Safety. Indian journal of public Health Reserch \& Development.

Tristantia, A. D. (2018). Evaluasi Sistem Pelaporan Insiden Keselamatan Pasien di Rumah Sakit. Jurnal Administrasi Kesehatan Indonesia. 6(2): 83-94.

Yasmi, Y. \& Hasbullah T. (2018). Faktor-Faktor yang Berhubungan dengan Budaya Keselamatan Pasien di Rumah Sakit Karya Bhakti Pratiwi 
Bogor Tahun 2015. Jurnal Administrasi

Rumah Sakit. 4(2): 98-109. 